\title{
Genetic modifiers of cancer risk in Lynch syndrome: a review
}

\author{
Bente A. Talseth-Palmer $\cdot$ Juul T. Wijnen • \\ Desma M. Grice • Rodney J. Scott
}

Published online: 8 March 2013

(c) The Author(s) 2013. This article is published with open access at Springerlink.com

\begin{abstract}
The report by Aldred Scott Warthin in 1913 of a cancer family history and expanded on by Henry $\mathrm{T}$. Lynch demonstrated one of the most enduring traits observed in patients with Lynch syndrome. The recognition of a variety of malignancies occurring at differing ages within a single family suggested the role of genetic variance on disease expression in an autosomal dominantly inherited genetic condition. With the identification of the genetic basis of Lynch syndrome and the subsequent collection of families and their medical records it has become possible to identify subtle genetic effects that influence the age at which disease onset occurs in this cancer predisposition. Knowledge about genetic modifiers influencing disease expression has the potential to be used to
\end{abstract}

B. A. Talseth-Palmer · D. M. Grice · R. J. Scott

School of Biomedical Sciences and Pharmacy, University

of Newcastle, Newcastle, Australia

B. A. Talseth-Palmer - D. M. Grice - R. J. Scott

Hunter Medical Research Institute, Newcastle, Australia

J. T. Wijnen

Centre for Human and Clinical Genetics, Leiden University

Medical Centre, Leiden, The Netherlands

D. M. Grice

Preventative Health Flagship, CSIRO, North Ryde,

NSW 2113, Australia

D. M. Grice

Animal, Food and Health Sciences, CSIRO, North Ryde,

NSW 2113, Australia

\section{R. J. Scott $(\square)$}

Division of Molecular Medicine, Hunter Area Pathology Service, John Hunter Hospital, Hunter New England Health District, Lookout Road, New Lambton, NSW 2305, Australia e-mail: Rodney.Scott@newcastle.edu.au personalise prophylactic screening measures to maximise the benefits for family members and their carers.

Keywords Lynch syndrome - Modifier genes - Disease expression $\cdot$ CRC susceptibility loci

\section{Introduction}

The primary function of mismatch repair (MMR) genes is to eliminate base-base mismatches and insertion-deletion loops which arise as a consequence of DNA polymerase slippage during DNA replication [1]. MMR confers several genetic stabilisation functions; it corrects DNA biosynthesis errors, ensures the fidelity of genetic recombination and participates in the earliest steps of checkpoint and apoptotic responses [2,3].

Lynch syndrome (LS) is associated with a breakdown in the efficiency of DNA MMR as a result of the loss of one or more DNA repair proteins from this process. Mutations in MSH2, MLH1, MSH6 or PMS2 decrease the fidelity of DNA replication as there is a failure to recognise and replace errors resulting from the mis-incorporation of bases by DNA polymerase. DNA MMR is a housekeeping function of all nucleated cells and as such any breakdown in the fidelity of this process is likely to result in disease irrespective of which gene is affected. Furthermore, mutations in DNA MMR genes result in a "mutator phenotype" thereby predisposing individuals to a significantly increased risk of malignancy.

It has been obvious from the first $M S H 2$ and $M L H 1$ mutation reports that differences in the ages of cancer diagnosis in patients harbouring germline mutations in DNA MMR genes do occur both within and between families. Furthermore, unrelated families harbouring the same mutation present with different disease profiles [4-6]. 
The differences in disease expression both within and between families harbouring the same mutation are most likely a result of environmental, genetic or a mixture of both influences. The search for environmental factors that could account for phenotypic variation is an almost intractable problem when studied retrospectively and is best undertaken prospectively, where as many factors can be included in any such analysis. In contrast, genetic factors can be studied retrospectively and therefore are more amenable to investigation. Ideally, both genetic and environmental factors should be studied together to identify those factors that can be modified by appropriate intervention. To the authors knowledge no such study has been undertaken to date and only genetic modifiers have been identified in LS at this time.

\section{Modifier genes}

The search for modifier genes has been ongoing ever since the first LS families were identified. Initial studies focused on genes associated with xenobiotic metabolism which have been followed by genes involved in the immune response, DNA repair, cell cycle control and as yet undefined genomic regions identified as a result of large genome wide association studies searching for genetic risk factors for colorectal cancer.

Initial studies in the search for genetic modifiers of disease focused on the biological plausibility of functional variants in a variety of different pathways that include but were not limited to xenobiotic clearance [7-12], cell cycle control, DNA repair [13-16], immunological activity and glycolysis [17-19]. The first reports on modifier genes also tended to be from small cohorts of patients [7-11, 13] where the confidence intervals of association were large. Many of the original studies have subsequently failed replication in larger cohorts, suggesting that the population size used in many of the initial reports was too small and therefore lacked statistical rigour. Nevertheless, some inferences were proposed that have appeared to hold up to greater scrutiny.

\section{Xenobiotic clearance and micronutrient metabolism}

The removal of many carcinogens is controlled by a complex process involving phase I enzymes such as cytochrome P450 (CYP), and phase II enzymes that include the glutathione-S-transferases (GSTs) and N-acetyl transferases (NATs) [20]. Polymorphisms in these genes have been associated with colorectal cancer but the precise roles that each variant has on cancer risk remains controversial [10-12, 21-28]. Genes involved in xenobiotic metabolism were therefore considered as ideal candidate modifier genes, as a result of their association with the risk of malignancy [20]. In the context of LS only a few reports have been forthcoming on the disease modifying effects of xenobiotic enzymes and have focused on NAT1, NAT2, GST and CYP.

The first study of an association between disease risk and polymorphisms in NAT2 in LS patients was reported in a small number of families where there was considerable disease diversity [7] and was later replicated in a second independent report [11]. Re-investigation of the association in two other unrelated patient cohorts failed to confirm any association [12, 24]. The failure to identify an association with NAT2 has since been indirectly confirmed in a review by Brockton et al. 2000 [28] who showed in 10 out of 11 studies of invasive CRC that NAT2 genotypes were not linked to disease risk.

Polymorphisms in GST and cytochrome p450 family 1, subfamily A, polypeptide 1 (CYP1Al) genes and their relationship to disease risk in LS have also been reported and have since come under scrutiny. There have been reports both for and against an association [8, 10, 12, 29]. In one study the Msp1 wildtype allele of CYP1Al was associated with a decreased risk of CRC but the allele distribution was not in Hardy-Weinberg equilibrium [12] thereby casting some doubt on the relationship. In this instance the evidence suggests that either a genotyping error that skews the results in favour of an association that is not real or it can be taken as supporting evidence for a correlation [30]. Two polymorphisms in CYPlAl have been associated with $\mathrm{CRC}[25,27]$, which taken together with the report of Talseth et al. 2006 [12] suggests that this gene is involved in some aspect of CRC development.

The association of xenobiotic clearance and disease expression in LS is complex and likely to be heavily influenced by environmental factors that are not easily identified or quantified. Nevertheless, future studies should take into consideration gene environment interactions to fully explain the contribution of xenobiotic enzyme polymorphisms with disease risk. This is highlighted in the findings from European compared to Asian populations where polymorphisms in GST show an association in the Korean population but not Australian or European [7, 10, 29].

Taken together, the assessment of xenobiotic modifier genes requires additional studies to delineate the environmental factors that in concert with their respective genetic variation affect the risk of disease.

\section{Cell cycle control}

Since DNA repair is integrally associated with cell cycle control, functional polymorphisms in genes associated with 
this aspect of genomic integrity are attractive candidates for modifier gene studies. The most well studied gene in this regard is the tumour suppressor gene TP53. TP53 is the most frequently mutated gene in a variety of cancers that include colorectal cancer [31]. TP53 has been called a master regulator as it is involved in the maintenance of genomic integrity, blocking cell proliferation after DNA damage and initiating apoptosis if it is too extensive $[32,33]$. In addition, there exists within any given population a common functional variant, R72P, which is estimated to occur at a frequency of approximately $35 \%$ in the general population [34]. The R72P SNP alters the function of TP53 $[35,36]$ and as such has been widely studied in a variety of malignancies [13, 37, 38].

In 2004 the age of colorectal cancer diagnosis in LS patients was found to be associated with the R72P polymorphism [13]. Subsequently, this association could not be replicated [15, 39]. The failure to identify an association with TP53 suggested that the positive effect observed in the first study [13] may have been related to the TP53 partner MDM2 that is also polymorphic. The effect of the polymorphism is to increase levels of MDM2 that results in the inability to stabilise TP53's cellular stress response [40]. Evidence implicating $M D M 2$ as a modifier gene could not be found in other studies [16].

Aurora-A and Cyclin D1, both necessary for cell cycle control, have also been associated with the age of onset of CRC in LS patients [41, 42] but replication studies have consistently failed to substantiate the initial findings [43]. Several reports in particular have focused on Cyclin D1 and most demonstrate no association [42, 44, 45]. In an Australian and Polish study an initial report suggested an association with $M S H 2$ mutation carriers [43] however, on expansion of the study population the original effect disappeared [46].

$A T M$ is another potential modifier that is involved in the control of the cell cycle. Two reports [14, 47] have examined a variant within the ATM gene producing diametrically opposed results. At this time, no conclusions can be made with respect to the potential role of ATM as a modifier gene in LS.

\section{DNA repair}

The role of DNA repair processes outside of the context of DNA mismatch repair represents a salient mechanism that could influence the age at which disease develops in LS. There are over 130 genes involved in DNA repair that all have significant roles in maintaining the veracity of the genome [48]. The DNA repair pathways of MMR and base excision repair (BER) are both involved in the identification, removal and repair of replication induced DNA errors.
The MMR system involves correcting mismatched bases that occur during DNA replication [1], whereas BER is highly specific for the repair of oxidative DNA damage [49]. Double-strand breaks (DSBs) in DNA are repaired by either non-homologous end joining (NHEJ) or homologous recombination (HR). Polymorphisms in DNA repair genes have been associated with cancer susceptibility suggesting that altered repair function may explain some of the phenotypic differences observed in LS. Only one report to date has examined a series of DNA repair gene polymorphisms in MSH3, OGG1, XRCC1, XRCC2, XRCC3, BRCA2 and Lig4 to determine if any could be associated with disease expression in LS [50]. None of the polymorphisms in the DNA repair genes listed could be shown to influence disease risk. The failure to identify any modifying effect does not rule out the possibility that there exist DNA repair gene polymorphisms that influence disease risk. Further studies of additional genes are required before it can be unequivocally stated that DNA repair gene polymorphisms are not associated with disease expression.

Telomerase is an enzyme involved in maintaining telomere length after cell division. Telomere shortening has been linked to the initiation of epithelial malignancies and chromosomal instability [51, 52]. A polymorphism in hTERT has been associated with cancer risk and one report has tentatively linked this polymorphism to an earlier age of cancer and/or polyp development in patients with LS [53]. Of interest in this report is the absence of effect in patients older than 45 years of age, suggesting that this modifier is no longer effective when telomere shortening has occurred in aging populations [54].

\section{Immunological function}

Tumours development is enhanced by an environment that supports tumour growth by promoting angiogenesis and facilitating genomic instability. The quintessential example is Crohns' disease where an increased risk of developing CRC is observed if the disease is left untreated [55]. Crohns' disease is an auto-immune disorder characterised by an over active pro-inflammatory response [56, 57]. Inflammatory responses can also increase DNA damage, growth stimulation and enhanced survival of damaged cells $[54,56]$. Many cytokines are polymorphic with effects that can alter transcription level and activity both in pro- and anti-inflammatory response genes.

Several polymorphisms in a number of cytokines have been investigated in relation to CRC risk and other cancer types but not for LS [58-65]. Genetic variation in pro- and anti-inflammatory cytokines has also been shown to influence the response to carcinogen exposure [64] [57] thereby suggesting that the immune response is integral to disease 
risk. With respect to LS no association has been identified in the one report focusing on a series of cytokine SNPs and disease expression [17].

Given the complexity of the inflammatory response and the limited number of SNPs examined, it cannot be ruled out that a relationship between SNPs influencing the immune response and LS exits.

\section{Growth factors}

Many growth factors are functionally polymorphic [66, 67] and have been shown to be associated with a variety of malignancies [68-71]. One growth factor that has received some attention is IGF-1. Several environmental and physiological reasons have been proposed that influence IGF-1 expression; however it has been only recently that evidence has accumulated suggesting a genetic role. Rosen et al. was the first to report that the length of the CA repeat region in $I G F-1$ may be associated with circulating IGF-1 levels [67].

In the context of LS IGF-1 appears to be particularly important, $I G F-1$. The function of $I G F-1$ is associated with cellular proliferation and differentiation and elevated levels of IGF-1 have been linked to CRC which is thought to be a result of the mitogenic and anti-apoptotic effects elicited by this protein [70, 71]. IGF- 1 was first reported as a potential modifying gene in LS disease expression in 2006 [18]. The CA-repeat polymorphism located near the $I G F-1$ promoter region was described as having an association with the age of disease onset in a cohort of 121 LS participants originating from the United States [18]. This result has been replicated in two additional populations, one from Australia [72] and a second from Poland [19]. Intriguingly, not only was there a relationship between CA repeat size but it appeared that the shorter CA-repeat the greater the effect. Given the paucity of replication of modifier gene effects it is encouraging to observe consistent effects are retained across different ethnicities [19].

The identification of a CA-repeat polymorphism in a growth factor gene associated with the age of colorectal cancer onset in LS suggests other CA-repeats that are functionally important in growth factor expression should be examined for their potential role as modifier genes in LS.

\section{Other modifiers}

A series of other modifier genes have been identified that appear to influence disease expression in LS. These include but are not limited to methylene tetrahydrofolate reductase (MTHFR) gene, the gene associated with haemochromatosis (Hfe) and a variety of other polymorphisms that occur in regions of the genome that do not as yet have any defined function. The latter polymorphisms have been identified from genome wide association studies examining genetic risk factors associated with colorectal cancer in the general population. A brief summary of what has been revealed follows:

Methylene tetrahydrofolate reductase (MTHFR)

There are a number of reports in the literature suggesting that polymorphisms in MTFHR are associated with colorectal cancer risk. Two functional polymorphisms in MTHFR (C677T and A1298C) have been the subject of intense scrutiny in relation to colorectal cancer risk as they both have significant effects on the activity of the protein product $[73,74]$. These two polymorphisms occur in relatively high frequency in the general population both have been associated with altered enzymatic function. MTHFR is a key folatemetabolizing enzyme involved in DNA methylation and DNA synthesis. The enzyme catalyses the irreversible conversion of 5,10-methylenetetrahydrofolate (5,10-MTHF), needed for purine and thymidine synthesis, to 5-methyltetrahydrofolate (5-MTHF), which is necessary for methionine production. Insufficient thymidine results in uracil misincorporation into DNA, leading to single-strand and double-strand breaks. Any change in the relative frequency of DNA damage will increase the risk of genetic instability.

Both A1298C and C677T are in high linkage disequilibrium [74] and only rarely has a MTHFR allele been identified that carries both the homozygote (C1298C/ T677T) variants of these polymorphisms [75-77]. Owing to this linkage disequilibrium, no studies have been reported where patients have inherited both homozygote variants in cis. Nevertheless, compound heterozygote carriers of 1298C and 677T have been identified. The effect of inheriting both alleles in trans effectively reduces overall MTHFR activity, thereby significantly altering the kinetics of folate metabolism. Evidence of the effects of MTHFR variants on disease expression in LS revealed that compound heterozygotes appeared to be significantly protected against an early age of disease onset [78]. The survival estimates predicted a median 10 year age difference for CRC onset in patients carrying the combined heterozygote MTHFR genotype which was supported by multi-variable regression modelling. The data also suggested this effect was significant in both $h M L H 1$ and $h M S H 2$ carriers, where previously only a significant association had been described in $h M L H 1$ for C677T only [79].

For individuals with a MMR deficiency, the effect of reduced MTHFR activity is potentially advantageous since uracil misincorporation could be particularly deleterious in conjunction with an impaired DNA repair pathway. 
Knowledge about the kinetics of MTHFR is significant in so far as dietary supplementation with folate (or withdrawal) may be a mechanism by which disease expression may be modulated in LS and may prove to be an indicator of individual disease risk in this syndrome.

\section{Haemochromatosis (Hfe)}

The iron overload disorder hereditary haemochromatosis $(\mathrm{HH})$ is characterised by high iron indices and progressive parenchymal iron overload due to unrestricted iron uptake [reviewed in [80-83]. The primary cause of classical HH is a result of polymorphisms in $H F E$, especially $845 G>A$ SNP which results in the substitution of a tyrosine residue for a cysteine at position 282 (C282Y), which is present in $10-15 \%$ of individuals of northern European descent. A second more common but less penetrant polymorphism, $163 C>G$ SNP (H63D) is present in 15-30\% of individuals [80, 83-89]. Patients homozygote for the C282Y polymorphism are about 3 times more likely to develop CRC compared to matched controls without the mutation [97]. There has been only one study examining the risk of CRC in LS suggestive of an effect. Homozygosity of the HFE H63D mutation may act as a disease risk modifier in LS [90], with as much as a 6 year difference in the age of disease onset for this less penetrant $\mathrm{HH}$ allele. In the study by Shi et al.; [90] there were too few $\mathrm{C} 282 \mathrm{Y}$ homozygotes to allow for any meaningful interpretation. While these findings will require substantiation in other populations, they support a possible relationship between iron dysregulation and colorectal cancer risk. An in-depth study of compound heterozygotes for both Hfe polymorphisms is required to firmly establish if iron status is indeed a risk factor for CRC in LS. It is well recognized that gender affects are significant in $\mathrm{HH}$ and males tend to fair less well than females. This may well be the case in LS as well but larger studies are necessary to assess the exact relationship of Hfe polymorphisms and colorectal cancer risk.

\section{DNA (cytosine-5-)-methyltransferase 3 beta} (DNMT3B)

DNA methylation is regulated by a family of DNA methyltransferases (DNMTs), of which three active forms (DNMT1, DNMT3A and DNMT3B) have been identified in mammalian cells [91]. A polymorphism located within $D N M T 3 B$ has been reported to influence enzyme expression as a result of altering its promoter activity. DNMT3B was proposed as a candidate in disease modifier due to its role in methylation. An example is the delta DNMT3B SNP, which was reported to be associated with an earlier age of CRC inset in LS [92]. A replication study, with over 400 individuals, failed to support the original report of an association between the age of CRC onset and the
DNMT3B polymorphism [93]. The failure to confirm the potential modifying influence of a polymorphism in one population compared to another could be simply due to insufficient numbers of test subjects. If a polymorphism is an affect modifier its response should be similar no matter what population is examined even though it may not reach statistical significance. In the case of the delta DNMT3B SNP no such trend was observed suggesting that the original observation may not have been statistically rigorous.

Polymorphisms identified from colorectal cancer genome-wide associations studies

There are several loci identified within the human genome that have been linked to CRC risk in the general population [94-99]. Many of the loci represent novel regions within the genome where little, if any, information is available concerning functional aspects of what these represent. Several groups have examined some of these SNPs in the context of their modifier effects. In 2009 two of the SNPs (rs16892766 and rs3802842) located on chromosomes 8 q23.3 and 11q23.1, respectively, were shown to be associated with an increased risk of developing CRC in Dutch LS patients [100]. This result was partially confirmed in a combined Australian and Polish report, where instead of there being a generalised effect on all LS patients, only those with MLH1 mutations were found to have an increased risk of CRC [101]. A third report from France, however, failed to replicate these findings [102]. More recently, a combined analysis of the Australian, Dutch and Polish LS totalling more than 1300 patients has confirmed the original findings and allowed for an additive analysis to determine whether one or more modifier alleles contribute further to disease risk [103]. At this point in time it is not entirely clear as to what functional effects rs3802842 has on disease risk as it resides in a region of chromosome 11 that harbours four open reading frames and does not result in any amino acid coding change thereby suggesting it may be regulatory in nature [104]. The SNP located on chromosome 8q23.3 maps to UTP23 [104] where it is presumed to alter the functional activity of the encoded protein.

\section{Continuing the search for modifier genes}

Thus far there is now some evidence to suggest that disease expression in LS is modified by genetic factors that are inherited independently of a causative mutation in one of the DNA mismatch repair genes. To date only a candidate gene (or locus) study has been performed to identify potential modifier genes in LS.

An alternative approach to screening candidate genes would be to undertake a genome-wide association study 
similar to that performed for carriers of BRCAl mutations which revealed a modifier locus on chromosome 19 [105]. This study required a total of 2383 BRCAl mutation carriers for the discovery phase of the project and a further 5986 BRCA1 mutation carriers for the replication phase [105]. Given that the carrier frequency of $B R C A 1$ is greater than that of all MMR gene mutation carriers combined it remains challenging to accumulate sufficient numbers of LS patients for a genome-wide association study, especially when there is some evidence to suggest that modifier effects may be specific to each MMR gene subgroup.

\section{Summary}

The search of modifier genes that influence disease expression in LS has revealed a number of potential candidates that could be used for individualised patient care. Several of the modifier genes reported to date are potentially valuable in terms of intervention strategies. Both Hfe and MTHFR must be confirmed in larger patient cohorts and if shown to be unequivocally associated with disease risks do offer avenues of potential risk reduction. Other candidate modifier loci do appear to be very promising as valuable additions to genetic screening for fine tuning surveillance strategies to maximise patient care and minimise unnecessary intervention. By including modifier genes/loci in risk algorithms it should be possible to tailor surveillance options for individual patients, which should allow for better outcomes in terms of patient acceptance of screening procedures resulting in reduced morbidity and mortality.

Open Access This article is distributed under the terms of the Creative Commons Attribution License which permits any use, distribution, and reproduction in any medium, provided the original author(s) and the source are credited.

\section{References}

1. Kunkel TA, Erie DA (2005) DNA mismatch repair. Annu Rev Biochem 74:681-710

2. Jiricny J (2006) The multifaceted mismatch-repair system. Nat Rev Mol Cell Biol 7(5):335-346

3. Bonis PA, Trikalinos TA, Chung M, Chew P, Ip S, DeVine DA, Lau J (2007) Hereditary nonpolyposis colorectal cancer: diagnostic strategies and their implications. Evid Rep Technol Assess (Full Rep) 150:1-180

4. Lynch HT, Smyrk TC, Watson P, Lanspa SJ, Lynch JF, Lynch PM, Cavalieri RJ, Boland CR (1993) Genetics, natural history, tumor spectrum, and pathology of hereditary nonpolyposis colorectal cancer: an updated review. Gastroenterology 104(5):1535-1549

5. Scott RJ, McPhillips M, Meldrum CJ, Fitzgerald PE, Adams K, Spigelman AD, du Sart D, Tucker K, Kirk J (2001) Hereditary nonpolyposis colorectal cancer in 95 families: differences and similarities between mutation-positive and mutation-negative kindreds. Am J Hum Genet 68(1):118-127

6. Rebbeck TR, Martinez ME, Sellers TA, Shields PG, Wild CP, Potter JD (2004) Genetic variation and cancer: improving the environment for publication of association studies. Cancer Epidemiol Biomarkers Prev 13(12):1985-1986

7. Heinimann K, Scott RJ, Chappuis P, Weber W, Muller H, Dobbie Z, Hutter P (1999) N-acetyltransferase 2 influences cancer prevalence in hMLH1/hMSH2 mutation carriers. Cancer Res 59(13):3038-3040

8. Campbell PT, Edwards L, McLaughlin JR, Green J, Younghusband HB, Woods MO (2007) Cytochrome P450 17A1 and catechol O-methyltransferase polymorphisms and age at Lynch syndrome colon cancer onset in Newfoundland. Clin Cancer Res 13(13):3783-3788

9. Esteller M, Garcia A, Martinez-Palones JM, Xercavins J, Reventos J (1997) Germ line polymorphisms in cytochrome-P450 1A1 (C4887 CYP1A1) and methylenetetrahydrofolate reductase (MTHFR) genes and endometrial cancer susceptibility. Carcinogenesis 18(12):2307-2311

10. Felix R, Bodmer W, Fearnhead NS, van der Merwe L, Goldberg P, Ramesar RS (2006) GSTM1 and GSTT1 polymorphisms as modifiers of age at diagnosis of hereditary nonpolyposis colorectal cancer (HNPCC) in a homogeneous cohort of individuals carrying a single predisposing mutation. Mutat Res 602(1-2): $175-181$

11. Frazier ML, O’Donnell FT, Kong S, Gu X, Campos I, Luthra R, Lynch PM, Amos CI (2001) Age-associated risk of cancer among individuals with $\mathrm{N}$-acetyltransferase 2 (NAT2) mutations and mutations in DNA mismatch repair genes. Cancer Res 61(4):1269-1271

12. Talseth BA, Meldrum C, Suchy J, Kurzawski G, Lubinski J, Scott RJ (2006) Genetic polymorphisms in xenobiotic clearance genes and their influence on disease expression in hereditary nonpolyposis colorectal cancer patients. Cancer Epidemiol Biomarkers Prev 15(11):2307-2310

13. Jones JS, Chi X, Gu X, Lynch PM, Amos CI, Frazier ML (2004) p53 polymorphism and age of onset of hereditary nonpolyposis colorectal cancer in a Caucasian population. Clin Cancer Res 10(17):5845-5849

14. Jones JS, Gu X, Lynch PM, Rodriguez-Bigas M, Amos CI, Frazier ML (2005) ATM polymorphism and hereditary nonpolyposis colorectal cancer (HNPCC) age of onset (United States). Cancer Causes Control 16(6):749-753

15. Talseth BA, Meldrum C, Suchy J, Kurzawski G, Lubinski J, Scott RJ (2006) Age of diagnosis of colorectal cancer in HNPCC patients is more complex than that predicted by $\mathrm{R} 72 \mathrm{P}$ polymorphism in TP53. Int J Cancer 118(10):2479-2484

16. Talseth BA, Meldrum C, Suchy J, Kurzawski G, Lubinski J, Scott RJ (2007) MDM2 SNP309 T > G alone or in combination with the TP53 R72P polymorphism does not appear to influence disease expression and age of diagnosis of colorectal cancer in HNPCC patients. Int J Cancer 120(3):563-565

17. Talseth BA, Meldrum C, Suchy J, Kurzawski G, Lubinski J, Scott RJ (2007) Lack of association between genetic polymorphisms in cytokine genes and disease expression in patients with hereditary non-polyposis colorectal cancer. Scand J Gastroenterol 42(5):628-632

18. Zecevic M, Amos CI, Gu X, Campos IM, Jones JS, Lynch PM, Rodriguez-Bigas MA, Frazier ML (2006) IGF1 gene polymorphism and risk for hereditary nonpolyposis colorectal cancer. J Natl Cancer Inst 98(2):139-143

19. Reeves SG, Rich D, Meldrum CJ, Colyvas K, Kurzawski G, Suchy J, Lubinski J, Scott RJ (2008) IGF1 is a modifier of disease risk in hereditary non-polyposis colorectal cancer. Int $\mathbf{J}$ Cancer 123(6):1339-1343 
20. Smith G, Stanley LA, Sim E, Strange RC, Wolf CR (1995) Metabolic polymorphisms and cancer susceptibility. Cancer Surv 25:27-65

21. He LJ, Yu YM, Qiao F, Liu JS, Sun XF, Jiang LL (2005) Genetic polymorphisms of $\mathrm{N}$-acetyltransferase 2 and colorectal cancer risk. World J Gastroenterol 11(27):4268-4271

22. Loktionov A, Watson MA, Gunter M, Stebbings WS, Speakman CT, Bingham SA (2001) Glutathione-S-transferase gene polymorphisms in colorectal cancer patients: interaction between GSTM1 and GSTM3 allele variants as a risk-modulating factor. Carcinogenesis 22(7):1053-1060

23. Moisio AL, Sistonen P, Mecklin JP, Jarvinen H, Peltomaki P (1998) Genetic polymorphisms in carcinogen metabolism and their association to hereditary nonpolyposis colon cancer. Gastroenterology 115(6):1387-1394

24. Pistorius S, Gorgens H, Kruger S, Engel C, Mangold E, Pagenstecher C, Holinski-Feder E, Moeslein G, von Knebel Doeberitz M, Ruschoff J, Karner-Hanusch J, Saeger HD, Schackert HK (2006) N-acetyltransferase (NAT) 2 acetylator status and age of onset in patients with hereditary nonpolyposis colorectal cancer (HNPCC). Cancer Lett 241(1):150-157

25. Sivaraman L, Leatham MP, Yee J, Wilkens LR, Lau AF, Le Marchand L (1994) CYP1A1 genetic polymorphisms and in situ colorectal cancer. Cancer Res 54(14):3692-3695

26. Slattery ML, Potter JD, Samowitz W, Bigler J, Caan B, Leppert M (1998) NAT2, GSTM-1, cigarette smoking, and risk of colon cancer. Cancer Epidemiol Biomarkers Prev 7(12):1079-1084

27. Ye Z, Parry JM (2002) Genetic polymorphisms in the cytochrome P450 1A1, glutathione S-transferase M1 and T1, and susceptibility to colon cancer. Teratog Carcinog Mutagen 22(5):385-392

28. Brockton N, Little J, Sharp L, Cotton SC (2000) N-acetyltransferase polymorphisms and colorectal cancer: a HuGE review. Am J Epidemiol 151(9):846-861

29. Shin JH, Ku JL, Shin KH, Shin YK, Kang SB, Park JG (2003) Glutathione S-transferase M1 associated with cancer occurrence in Korean HNPCC families carrying the hMLH1/hMSH2 mutation. Oncol Rep 10(2):483-486

30. Gyorffy B, Kocsis I, Vasarhelyi B (2004) Biallelic genotype distributions in papers published in Gut between 1998 and 2003: altered conclusions after recalculating the Hardy-Weinberg equilibrium. Gut 53(4):614-615 author reply 615-6

31. Levine AJ, Oren M (2009) The first 30 years of p53: growing ever more complex. Nat Rev Cancer 9(10):749-758

32. Levine AJ (1997) p53, the cellular gatekeeper for growth and division. Cell 88(3):323-331

33. Xu H, el-Gewely MR (2001) P53-responsive genes and the potential for cancer diagnostics and therapeutics development. Biotechnol Annu Rev 7:131-164

34. Schmidt MK, Tommiska J, Broeks A, van Leeuwen FE, Van't Veer LJ, Pharoah PD, Easton DF, Shah M, Humphreys M, Dork T, Reincke SA, Fagerholm R, Blomqvist C, Nevanlinna H (2009) Combined effects of single nucleotide polymorphisms TP53 R72P and MDM2 SNP309, and p53 expression on survival of breast cancer patients. Breast Cancer Res 11(6):R89

35. Pim D, Banks L (2004) p53 polymorphic variants at codon 72 exert different effects on cell cycle progression. Int $\mathrm{J}$ Cancer 108(2):196-199

36. Wang YC, Chen CY, Chen SK, Chang YY, Lin P (1999) p53 codon 72 polymorphism in Taiwanese lung cancer patients: association with lung cancer susceptibility and prognosis. Clin Cancer Res 5(1):129-134

37. Bergamaschi G, Merante S, Orlandi E, Galli A, Bernasconi P, Cazzola M (2004) TP53 codon 72 polymorphism in patients with chronic myeloid leukemia. Haematologica 89(7):868-869
38. Cortezzi SS, Provazzi PJ, Sobrinho JS, Mann-Prado JC, Reis PM, de Freitas SE, Filho JF, Fukuyama EE, Cordeiro JA, Cury PM, Maniglia JV, Villa LL, Tajara EH, Rahal P (2004) Analysis of human papillomavirus prevalence and TP53 polymorphism in head and neck squamous cell carcinomas. Cancer Genet Cytogenet 150(1):44-49

39. Sotamaa K, Liyanarachchi S, Mecklin JP, Jarvinen H, Aaltonen LA, Peltomaki P, de la Chapelle A (2005) p53 codon 72 and MDM2 SNP309 polymorphisms and age of colorectal cancer onset in Lynch syndrome. Clin Cancer Res 11(19 Pt 1): 6840-6844

40. Bond GL, Hu W, Bond EE, Robins H, Lutzker SG, Arva NC, Bargonetti J, Bartel F, Taubert H, Wuerl P, Onel K, Yip L, Hwang SJ, Strong LC, Lozano G, Levine AJ (2004) A single nucleotide polymorphism in the MDM2 promoter attenuates the p53 tumor suppressor pathway and accelerates tumor formation in humans. Cell 119(5):591-602

41. Chen J, Sen S, Amos CI, Wei C, Jones JS, Lynch P, Frazier ML (2007) Association between Aurora-A kinase polymorphisms and age of onset of hereditary nonpolyposis colorectal cancer in a Caucasian population. Mol Carcinog 46(4):249-256

42. Kruger S, Engel C, Bier A, Mangold E, Pagenstecher C, Doeberitz MK, Holinski-Feder E, Moeslein G, Keller G, Kunstmann E, Friedl W, Plaschke J, Ruschoff J, Schackert HK (2006) Absence of association between cyclin D1 (CCND1) G870A polymorphism and age of onset in hereditary nonpolyposis colorectal cancer. Cancer Lett 236(2):191-197

43. Talseth BA, Ashton KA, Meldrum C, Suchy J, Kurzawski G, Lubinski J, Scott RJ (2008) Aurora-A and Cyclin D1 polymorphisms and the age of onset of colorectal cancer in hereditary nonpolyposis colorectal cancer. Int J Cancer 122(6):1273-1277

44. Kong S, Amos CI, Luthra R, Lynch PM, Levin B, Frazier ML (2000) Effects of cyclin D1 polymorphism on age of onset of hereditary nonpolyposis colorectal cancer. Cancer Res 60(2):249-252

45. Bala S, Peltomaki P (2001) CYCLIN D1 as a genetic modifier in hereditary nonpolyposis colorectal cancer. Cancer Res 61(16): 6042-6045

46. Scott RJ, Reeves S, Talseth-Palmer B (2012) The role of modifier genes in Lynch Syndrome. 1st ed. Colorectal Cancer Biology-From Genes To Tumor Croatia: In Tech

47. Maillet P, Chappuis PO, Vaudan G, Dobbie Z, Muller H, Hutter P, Sappino AP (2000) A polymorphism in the ATM gene modulates the penetrance of hereditary non-polyposis colorectal cancer. Int J Cancer 88(6):928-931

48. Wood RD, Mitchell M, Sgouros J, Lindahl T (2001) Human DNA repair genes. Science 291(5507):1284-1289

49. David SS, O'Shea VL, Kundu S (2007) Base-excision repair of oxidative DNA damage. Nature 447(7147):941-950

50. Reeves SG, Meldrum C, Groombridge C, Spigelman A, Suchy J, Kurzawski G, Lubinski J, Scott RJ (2012) DNA repair gene polymorphisms and risk of early onset colorectal cancer in Lynch syndrome. Cancer Epidemiol 36(2):183-189

51. Meeker AK, Argani P (2004) Telomere shortening occurs early during breast tumorigenesis: a cause of chromosome destabilization underlying malignant transformation? J Mammary Gland Biol Neoplasia 9(3):285-296

52. Londono-Vallejo JA, Der-Sarkissian H, Cazes L, Bacchetti S, Reddel RR (2004) Alternative lengthening of telomeres is characterized by high rates of telomeric exchange. Cancer Res 64(7):2324-2327

53. Bellido F, Guino E, Jagmohan-Changur S, Segui N, Pineda M, Navarro M, Lazaro C, Blanco I, Vasen HF, Moreno V, Capella G, Wijnen JT, and Valle L, (2012) Genetic variant in the telomerase gene modifies cancer risk in Lynch syndrome. Eur $\mathbf{J}$ Hum Genet 
54. Djojosubroto MW, Choi YS, Lee HW, Rudolph KL (2003) Telomeres and telomerase in aging, regeneration and cancer. Mol Cells 15(2):164-175

55. Balkwill F, Mantovani A (2001) Inflammation and cancer: back to Virchow? Lancet 357(9255):539-545

56. Coussens LM, Werb Z (2002) Inflammation and cancer. Nature 420(6917):860-867

57. Danese $S$ (2012) New therapies for inflammatory bowel disease: from the bench to the bedside. Gut 61(6):918-932

58. Duarte I, Santos A, Sousa H, Catarino R, Pinto D, Matos A, Pereira D, Moutinho J, Canedo P, Machado JC, Medeiros R (2005) G-308A TNF-alpha polymorphism is associated with an increased risk of invasive cervical cancer. Biochem Biophys Res Commun 334(2):588-592

59. El-Omar EM, Rabkin CS, Gammon MD, Vaughan TL, Risch HA, Schoenberg JB, Stanford JL, Mayne ST, Goedert J, Blot WJ, Fraumeni JF Jr, Chow WH (2003) Increased risk of noncardia gastric cancer associated with proinflammatory cytokine gene polymorphisms. Gastroenterology 124(5):1193-1201

60. Giordani L, Bruzzi P, Lasalandra C, Quaranta M, Schittulli F, Della Ragione F, Iolascon A (2003) Association of breast cancer and polymorphisms of interleukin-10 and tumor necrosis factoralpha genes. Clin Chem 49(10):1664-1667

61. Hefler LA, Grimm C, Ackermann S, Malur S, Radjabi-Rahat AR, Leodolter S, Beckmann MW, Zeillinger R, Koelbl H, Tempfer CB (2003) An interleukin-6 gene promoter polymorphism influences the biological phenotype of ovarian cancer. Cancer Res 63(12):3066-3068

62. Iacopetta B, Grieu F, Joseph D (2004) The -174 G/C gene polymorphism in interleukin-6 is associated with an aggressive breast cancer phenotype. Br J Cancer 90(2):419-422

63. Ikeda H, Old LJ, Schreiber RD (2002) The roles of IFN gamma in protection against tumor development and cancer immunoediting. Cytokine Growth Factor Rev 13(2):95-109

64. Landi S, Moreno V, Gioia-Patricola L, Guino E, Navarro M, de Oca J, Capella G, Canzian F (2003) Association of common polymorphisms in inflammatory genes interleukin (IL)6, IL8, tumor necrosis factor alpha, NFKB1, and peroxisome proliferator-activated receptor gamma with colorectal cancer. Cancer Res 63(13):3560-3566

65. Graziano F, Ruzzo A, Santini D, Humar B, Tonini G, Catalano V, Berardi R, Pizzagalli F, Arduini F, Bearzi I, Scartozzi M, Cascinu S, Testa E, Ficarelli R, Magnani M (2005) Prognostic role of interleukin-1beta gene and interleukin-1 receptor antagonist gene polymorphisms in patients with advanced gastric cancer. J Clin Oncol 23(10):2339-2345

66. Gebhardt F, Zanker KS, Brandt B (1999) Modulation of epidermal growth factor receptor gene transcription by a polymorphic dinucleotide repeat in intron 1. J Biol Chem 274(19):13176-13180

67. Rosen CJ, Kurland ES, Vereault D, Adler RA, Rackoff PJ, Craig WY, Witte S, Rogers J, Bilezikian JP (1998) Association between serum insulin growth factor-I (IGF-I) and a simple sequence repeat in IGF-I gene: implications for genetic studies of bone mineral density. J Clin Endocrinol Metab 83(7):2286-2290

68. Sugaya K, Nishijima S, Yamada T, Miyazato M, Hatano T, Ogawa Y (2002) Molecular analysis of adrenergic receptor genes and interleukin-4/interleukin-4 receptor genes in patients with interstitial cystitis. J Urol 168(6):2668-2671

69. Xue W, Irvine RA, Yu MC, Ross RK, Coetzee GA, Ingles SA (2000) Susceptibility to prostate cancer: interaction between genotypes at the androgen receptor and prostate-specific antigen loci. Cancer Res 60(4):839-841

70. Giovannucci E (2001) Insulin, insulin-like growth factors and colon cancer: a review of the evidence. J Nutr 131(11 Suppl):3109S-3120S
71. Chen W, Wang S, Tian T, Bai J, Hu Z, Xu Y, Dong J, Chen F, Wang X, Shen H (2009) Phenotypes and genotypes of insulinlike growth factor 1, IGF-binding protein-3 and cancer risk: evidence from 96 studies. Eur J Hum Genet 17(12):1668-1675

72. Reeves S, Meldrum C, Scott RJ (2006) IGF-1 gene polymorphism and risk for hereditary nonpolyposis colorectal cancer. J Natl Cancer Inst 98(22):1664-1665 author reply 1665

73. Yin G, Kono S, Toyomura K, Hagiwara T, Nagano J, Mizoue T, Mibu R, Tanaka M, Kakeji Y, Maehara Y, Okamura T, Ikejiri K, Futami K, Yasunami Y, Maekawa T, Takenaka K, Ichimiya H, Imaizumi N (2004) Methylenetetrahydrofolate reductase C677T and A1298C polymorphisms and colorectal cancer: the Fukuoka Colorectal Cancer Study. Cancer Sci 95(11):908-913

74. Weisberg I, Tran P, Christensen B, Sibani S, Rozen R (1998) A second genetic polymorphism in methylenetetrahydrofolate reductase (MTHFR) associated with decreased enzyme activity. Mol Genet Metab 64(3):169-172

75. Chen J, Ma J, Stampfer MJ, Palomeque C, Selhub J, Hunter DJ (2002) Linkage disequilibrium between the $677 \mathrm{C}>\mathrm{T}$ and 1298A > C polymorphisms in human methylenetetrahydrofolate reductase gene and their contributions to risk of colorectal cancer. Pharmacogenetics 12(4):339-342

76. Sharp L, Little J (2004) Polymorphisms in genes involved in folate metabolism and colorectal neoplasia: a HuGE review. Am J Epidemiol 159(5):423-443

77. Giovannucci E (2002) Epidemiologic studies of folate and colorectal neoplasia: a review. J Nutr 132(8 Suppl):2350S2355S

78. Reeves SG, Meldrum C, Groombridge C, Spigelman AD, Suchy J, Kurzawski G, Lubinski J, McElduff P, Scott RJ (2009) MTHFR $677 \mathrm{C}>\mathrm{T}$ and $1298 \mathrm{~A}>\mathrm{C}$ polymorphisms and the age of onset of colorectal cancer in hereditary nonpolyposis colorectal cancer. Eur J Hum Genet 17(5):629-635

79. Pande M, Chen J, Amos CI, Lynch PM, Broaddus R, Frazier ML (2007) Influence of methylenetetrahydrofolate reductase gene polymorphisms C677T and A1298C on age-associated risk for colorectal cancer in a caucasian lynch syndrome population. Cancer Epidemiol Biomarkers Prev 16(9):1753-1759

80. Beutler E (2006) Hemochromatosis: genetics and pathophysiology. Annu Rev Med 57:331-347

81. Camaschella C (2005) Understanding iron homeostasis through genetic analysis of hemochromatosis and related disorders. Blood 106(12):3710-3717

82. Pietrangelo A (2006) Hereditary hemochromatosis. Annu Rev Nutr 26:251-270

83. Olynyk JK, Cullen DJ, Aquilia S, Rossi E, Summerville L, Powell LW (1999) A population-based study of the clinical expression of the hemochromatosis gene. $\mathrm{N}$ Engl $\mathrm{J}$ Med 341(10):718-724

84. Whitlock EP, Garlitz BA, Harris EL, Beil TL, Smith PR (2006) Screening for hereditary hemochromatosis: a systematic review for the U.S. Preventive Services Task Force. Ann Intern Med 145(3):209-223

85. Chua AC, Graham RM, Trinder D, Olynyk JK (2007) The regulation of cellular iron metabolism. Crit Rev Clin Lab Sci 44(5-6):413-459

86. Gochee PA, Powell LW, Cullen DJ, Du Sart D, Rossi E, Olynyk JK (2002) A population-based study of the biochemical and clinical expression of the H63D hemochromatosis mutation. Gastroenterology 122(3):646-651

87. Jackson HA, Carter K, Darke C, Guttridge MG, Ravine D, Hutton RD, Napier JA, Worwood M (2001) HFE mutations, iron deficiency and overload in 10,500 blood donors. Br J Haematol 114(2):474-484

88. Milman N, Pedersen P, Ovesen L, Melsen GV, Fenger K (2004) Frequency of the $\mathrm{C} 282 \mathrm{Y}$ and H63D mutations of the 
hemochromatosis gene (HFE) in 2501 ethnic Danes. Ann Hematol 83(10):654-657

89. Steinberg KK, Cogswell ME, Chang JC, Caudill SP, McQuillan GM, Bowman BA, Grummer-Strawn LM, Sampson EJ, Khoury MJ, Gallagher ML (2001) Prevalence of C282Y and H63D mutations in the hemochromatosis (HFE) gene in the United States. JAMA 285(17):2216-2222

90. Shi Z, Johnstone D, Talseth-Palmer BA, Evans TJ, Spigelman $\mathrm{AD}$, Groombridge C, Milward EA, Olynyk JK, Suchy J, Kurzawski G, Lubinski J, Scott RJ (2009) Haemochromatosis HFE gene polymorphisms as potential modifiers of hereditary nonpolyposis colorectal cancer risk and onset age. Int $\mathbf{J}$ Cancer 125(1):78-83

91. Shen H, Wang L, Spitz MR, Hong WK, Mao L, Wei Q (2002) A novel polymorphism in human cytosine DNA-methyltransferase-3B promoter is associated with an increased risk of lung cancer. Cancer Res 62(17):4992-4995

92. Jones JS, Amos CI, Pande M, Gu X, Chen J, Campos IM, Wei Q, Rodriguez-Bigas M, Lynch PM, Frazier ML (2006) DNMT3b polymorphism and hereditary nonpolyposis colorectal cancer age of onset. Cancer Epidemiol Biomarkers Prev 15(5):886-891

93. Reeves SG, Mossman D, Meldrum CJ, Kurzawski G, Suchy J, Lubinski J, Scott RJ (2008) The $-149 \mathrm{C}>\mathrm{T}$ SNP within the DeltaDNMT3B gene, is not associated with early disease onset in hereditary non-polyposis colorectal cancer. Cancer Lett 265(1):39-44

94. Dunlop MG, Dobbins SE, Farrington SM, Jones AM, Palles C, Whiffin N, Tenesa A, Spain S, Broderick P, Ooi LY, Domingo E, Smillie C, Henrion M, Frampton M, Martin L, Grimes G, Gorman M, Semple C, Ma YP, Barclay E, Prendergast J, Cazier JB, Olver B, Penegar S, Lubbe S, Chander I, Carvajal-Carmona LG, Ballereau S, Lloyd A, Vijayakrishnan J, Zgaga L, Rudan I, Theodoratou E, Starr JM, Deary I, Kirac I, Kovacevic D, Aaltonen LA, Renkonen-Sinisalo L, Mecklin JP, Matsuda K, Nakamura Y, Okada Y, Gallinger S, Duggan DJ, Conti D, Newcomb P, Hopper J, Jenkins MA, Schumacher F, Casey G, Easton D, Shah M, Pharoah P, Lindblom A, Liu T, Smith CG, West H, Cheadle JP, Midgley R, Kerr DJ, Campbell H, Tomlinson IP, Houlston RS (2012) Common variation near CDKN1A, POLD3 and SHROOM2 influences colorectal cancer risk. Nat Genet 44(7):770-776

95. Houlston RS, Cheadle J, Dobbins SE, Tenesa A, Jones AM, Howarth K, Spain SL, Broderick P, Domingo E, Farrington S, Prendergast JG, Pittman AM, Theodoratou E, Smith CG, Olver B, Walther A, Barnetson RA, Churchman M, Jaeger EE, Penegar S, Barclay E, Martin L, Gorman M, Mager R, Johnstone E, Midgley R, Niittymaki I, Tuupanen S, Colley J, Idziaszczyk S, Thomas HJ, Lucassen AM, Evans DG, Maher ER, Maughan T, Dimas A, Dermitzakis E, Cazier JB, Aaltonen LA, Pharoah P, Kerr DJ, Carvajal-Carmona LG, Campbell H, Dunlop MG, Tomlinson IP (2010) Meta-analysis of three genome-wide association studies identifies susceptibility loci for colorectal cancer at 1q41,3q26.2, 12q13.13 and 20q13.33. Nat Genet 42(11):973-977

96. Houlston RS, Webb E, Broderick P, Pittman AM, Di Bernardo MC, Lubbe S, Chandler I, Vijayakrishnan J, Sullivan K, Penegar S, Carvajal-Carmona L, Howarth K, Jaeger E, Spain SL, Walther A, Barclay E, Martin L, Gorman M, Domingo E, Teixeira AS, Kerr D, Cazier JB, Niittymaki I, Tuupanen S, Karhu A, Aaltonen LA, Tomlinson IP, Farrington SM, Tenesa A, Prendergast JG, Barnetson RA, Cetnarskyj R, Porteous ME, Pharoah PD, Koessler T, Hampe J, Buch S, Schafmayer C, Tepel J, Schreiber S, Volzke H, Chang-Claude J, Hoffmeister M, Brenner H, Zanke BW, Montpetit A, Hudson TJ, Gallinger S, Campbell H, Dunlop MG (2008) Meta-analysis of genome-wide association data identifies four new susceptibility loci for colorectal cancer. Nat Genet 40(12):1426-1435

97. Broderick P, Carvajal-Carmona L, Pittman AM, Webb E, Howarth K, Rowan A, Lubbe S, Spain S, Sullivan K, Fielding S, Jaeger E, Vijayakrishnan J, Kemp Z, Gorman M, Chandler I, Papaemmanuil E, Penegar S, Wood W, Sellick G, Qureshi M, Teixeira A, Domingo E, Barclay E, Martin L, Sieber O, Kerr D, Gray R, Peto J, Cazier JB, Tomlinson I, Houlston RS (2007) A genome-wide association study shows that common alleles of SMAD7 influence colorectal cancer risk. Nat Genet 39(11): 1315-1317

98. Tenesa A, Farrington SM, Prendergast JG, Porteous ME, Walker M, Haq N, Barnetson RA, Theodoratou E, Cetnarskyj R, Cartwright N, Semple C, Clark AJ, Reid FJ, Smith LA, Kavoussanakis K, Koessler T, Pharoah PD, Buch S, Schafmayer C, Tepel J, Schreiber S, Volzke H, Schmidt CO, Hampe J, ChangClaude J, Hoffmeister M, Brenner H, Wilkening S, Canzian F, Capella G, Moreno V, Deary IJ, Starr JM, Tomlinson IP, Kemp Z, Howarth K, Carvajal-Carmona L, Webb E, Broderick P, Vijayakrishnan J, Houlston RS, Rennert G, Ballinger D, Rozek L, Gruber SB, Matsuda K, Kidokoro T, Nakamura Y, Zanke BW, Greenwood CM, Rangrej J, Kustra R, Montpetit A, Hudson TJ, Gallinger S, Campbell H, Dunlop MG (2008) Genome-wide association scan identifies a colorectal cancer susceptibility locus on 11q23 and replicates risk loci at 8q24 and 18q21. Nat Genet 40(5):631-637

99. Tomlinson IP, Webb E, Carvajal-Carmona L, Broderick P, Howarth K, Pittman AM, Spain S, Lubbe S, Walther A, Sullivan K, Jaeger E, Fielding S, Rowan A, Vijayakrishnan J, Domingo E, Chandler I, Kemp Z, Qureshi M, Farrington SM, Tenesa A, Prendergast JG, Barnetson RA, Penegar S, Barclay E, Wood W, Martin L, Gorman M, Thomas H, Peto J, Bishop DT, Gray R, Maher ER, Lucassen A, Kerr D, Evans DG, Schafmayer C, Buch S, Volzke H, Hampe J, Schreiber S, John U, Koessler T, Pharoah P, van Wezel T, Morreau H, Wijnen JT, Hopper JL, Southey MC, Giles GG, Severi G, Castellvi-Bel S, Ruiz-Ponte C, Carracedo A, Castells A, Forsti A, Hemminki K, Vodicka P, Naccarati A, Lipton L, Ho JW, Cheng KK, Sham PC, Luk J, Agundez JA, Ladero JM, de la Hoya M, Caldes T, Niittymaki I, Tuupanen S, Karhu A, Aaltonen L, Cazier JB, Campbell H, Dunlop MG, Houlston RS (2008) A genome-wide association study identifies colorectal cancer susceptibility loci on chromosomes 10p14 and 8q23.3. Nat Genet 40(5):623-630

100. Wijnen JT, Brohet RM, van Eijk R, Jagmohan-Changur S, Middeldorp A, Tops CM, van Puijenbroek M, Ausems MG, Gomez Garcia E, Hes FJ, Hoogerbrugge N, Menko FH, van Os TA, Sijmons RH, Verhoef S, Wagner A, Nagengast FM, Kleibeuker JH, Devilee P, Morreau H, Goldgar D, Tomlinson IP, Houlston RS, van Wezel T, Vasen HF (2009) Chromosome $8 \mathrm{q} 23.3$ and $11 \mathrm{q} 23.1$ variants modify colorectal cancer risk in Lynch syndrome. Gastroenterology 136(1):131-137

101. Talseth-Palmer BA, Brenne IS, Ashton KA, Evans TJ, McPhillips M, Groombridge C, Suchy J, Kurzawski G, Spigelman A, Lubinski J, Scott RJ (2011) Colorectal cancer susceptibility loci on chromosome 8q23.3 and 11q23.1 as modifiers for disease expression in Lynch syndrome. J Med Genet 48(4): 279-284

102. Houlle S, Charbonnier F, Houivet E, Tinat J, Buisine MP, Caron O, Benichou J, Baert-Desurmont S, Frebourg T (2011) Evaluation of Lynch syndrome modifier genes in 748 MMR mutation carriers. Eur J Hum Genet 19(8):887-892

103. Talseth-Palmer BA, Wijnen JT, Brenne IS, Jagmohan-Changur S, Barker D, Ashton KA, Tops CM, Evans TJ, McPhillips M, Groombridge C, Suchy J, Kurzawski G, Spigelman A, Moller P, Morreau HM, Wezel TV, Lubinski J, Vasen HF, and Scott RJ (2012) Combined analysis of three Lynch syndrome cohorts 
confirms the modifying effects of 8q23.3 and 11q23.1 in MLH1 mutation carriers. Int $\mathrm{J}$ Cancer

104. Carvajal-Carmona LG, Cazier JB, Jones AM, Howarth K, Broderick P, Pittman A, Dobbins S, Tenesa A, Farrington S, Prendergast J, Theodoratou E, Barnetson R, Conti D, Newcomb P, Hopper JL, Jenkins MA, Gallinger S, Duggan DJ, Campbell H, Kerr D, Casey G, Houlston R, Dunlop M, Tomlinson I (2011) Fine-mapping of colorectal cancer susceptibility loci at 8q23.3, 16q22.1 and 19q13.11: refinement of association signals and use of in silico analysis to suggest functional variation and unexpected candidate target genes. Hum Mol Genet 20(14): 2879-2888

105. Antoniou AC, Chenevix-Trench G (2010) Common genetic variants and cancer risk in Mendelian cancer syndromes. Curr Opin Genet Dev 20(3):299-307 